\title{
LITERARY STUDIES OF IBRAHIM RUGOVA
}

\author{
MA Leonora Bruçaj \\ PhD Candidate at University of Prishtina "Hasan Prishtina"
}

\begin{abstract}
Ibrahim Rugova looked at the poetic literary work in the complexity of theoretical and practical realization, in the totality of the functioning and acceptance of the work and its aesthetic impact on the recipient. Seeing and studying the literary work as an open and complex phenomenon, Rugova researched the connotative-semantic aspect, as a result of the special linguistic-poetic structuring, thus observing what a literary work can mean, especially the form and the way it is said. Within this contemplation of the literary work and the complex process of its shaping, Rugova implemented his own system of opinion, application and realization. Good knowledge of literary theory and practice helped him accomplish this. His opinion on some literary phenomena and especially on some of the most important works of Albanian literature, such as those of Xoxa, Kadare, Podrimja, etc., does not appear to be imposing a priori. The depth and conciseness of his opinion derive from the conception, organization, extrication - analysis of the phenomena which he considers. The author does not say and does not intentionally force the assertion with rhetorical expressions, but he does so through consistent opinion, as a result of prior devotional study and analysis.

Rugova is the rare Albanian model of the scholar formed in the Paris school, as a follower of Janet and Bart, contextualized with European contemporaneity as a modern voice of Paris school, but, before arriving here, he was a continuer of the National Renaissance, as a cultural and political resistance, which, constrained by historical circumstances, was forced to remain current in Kosovo which demanded freedom and statehood.

In his studies, Ibrahim Rugova always leaves the possibility of observing the phenomena from other points of view, even the ones that are different from what he does. This happens because the literary work is observed as a phenomenon that everyone reads and communicates in their own way, depending on the level of theoretical preparation and knowledge of literary practice, receptive aesthetics, but also beyond it.
\end{abstract}

Keywords: Rugova, Albanian literary work, theory, Bart, poetic, literature

\section{Introduction}

Ibrahim Rugova left behind such a rich and special legacy in the field of literary studies. This is evidenced by a series of his works with great value which illuminate theoretical and aesthetic issues of literature as the art of speech and are interpreted in a series of literary works as a set of expressive and semantic texts such as, Prekje lirike (Lyrical Touch) (1971), Kah teoria (Towards Theory) (1978), Strategjia e kuptimit (Strategy of the Meaning) (1980), Vepra e Bogdanit 1675 - 1685 (Bogdan's Works 1675 - 1685) (1982), Kahe dhe premisa të kritikës letrare shqiptare 1504 - 1983 (Directions and Premises of Albanian Literary Criticism 1504 - 1983) (1986), Refuzimi estetik (Aesthetic Rejection) (1987).

They are distinguished not only for the multiplicity of phenomena observed, for the interpretations of works of Albanian literature and other literatures, but also for their modern approach, which uses a rich system of notions that is applied in the study of major literatures. This detached our literary study from the positivist approach that was 
ISSN 2661-2666 (Online) International Scientific Journal Monte (ISJM) DOI: 10.33807/monte.20211848

Volume 4, (No).1 (2021): April

deeply ingrained in it. Ibrahim Rugova looked at the poetic literary work in the complexity of theoretical and practical realization, in the totality of the functioning and acceptance of the work and its aesthetic impact on the recipient. Seeing and studying the literary work as an open and complex phenomenon, Rugova researched the connotative-semantic aspect, as a result of the special linguistic-poetic structuring, thus observing what a literary work can mean, especially the form and the way it is said. Within this contemplation of the literary work and the complex process of its shaping, Rugova implemented his own system of opinion, application and realization. Good knowledge of literary theory and practice helped him accomplish this. His opinion on some literary phenomena and especially on some of the most important works of Albanian literature, such as those of Xoxa, Kadare, Podrimja, etc., does not appear to be imposing a priori. The depth and conciseness of his opinion derive from the conception, organization, extrication - analysis of the phenomena which he considers. The author does not say and does not intentionally force the assertion with rhetorical expressions, but he does so through consistent opinion, as a result of prior devotional study and analysis.

"On the other hand, Ibrahim Rugova belongs to the generation of 1968 and to the cultural circle of Prishtina. At the end of the sixties of the twentieth century, Prishtina became a university city, led by a strong student and cultural movement which gathered for the first time the young people of Albanian lands, in Kosovo and around it. This cultural and intellectual movement, quite naturally established its centre in the University of Prishtina in order to spread its liberating influence to other strata of society. The power of this movement was focused on culture and creativity, with the strongest articulation in literature, with the strong national and authentic insignia perpetuated immediately at modernity. In these years Prishtina, as well as all of Kosovo, had a daily newspaper, a literary magazine, a radio, a publishing house in Albanian language. The cultural and intellectual movement, concentrated in the university generation, established its own cultural newspaper, its own cultural magazine, and it created its own publishing house. This, in an unannounced way, articulated the alternative of the ruling ace in culture. (Hamiti, 2007 p. 15.)

We can say that it was the circle of Prishtina that could be considered as the second cultural modernizing movement of Albanian literature, if with the first movement can be understood the cultural movement of the 1930s. In this context, for the first time in the history of Albanian literature, the authors of this circle pass the social function of literature to the second, third or fourth plane, returning to it the aesthetic function as a primary function.

Rugova is the rare Albanian model of the scholar formed in the Paris school, as a follower of Janet and Bart, contextualized with European contemporaneity as a modern voice of Paris school, but, before arriving here, he was a continuer of the National Renaissance, as a cultural and political resistance, which, constrained by historical circumstances, was forced to remain current in Kosovo which demanded freedom and statehood.

Ibrahim Rugova started his first writings in literature with poetry, as all writers probably do when they start dealing with literature. He published somewhere around twenty poems which were at the level of the poems being published 
ISSN 2661-2666 (Online) International Scientific Journal Monte (ISJM) DOI: 10.33807/monte.20211848

Volume 4, (No).1 (2021): April

at the time. But, he soon abandoned this genre to devote himself to the study of literature, especially literary criticism. Even in his first collection of writings in this field, in the "Prekje lirike" (Lyrical Touch) 1971, he proved to have a tendency towards advanced Western literature, avoiding that of socialist realism which had overwhelmed a part of the literature of the so-called socialist camp, an area to which both Albania but also Kosovo, as an integral part of the then Yugoslavia, belonged. It should be noted that the works of this book were first published in the periodical magazine "Fjala" (Word) with the title "Zenite letrare" (Literary Zeniths) which showed his orientation towards dealing with the highest peaks of, mainly world, literature. In this context, a further look should be given to the efforts of this creator to get rid of the dogmas of socialist realism which had overwhelmed the literature that was being created at that time, especially what was being created in Albania and which, in a way, was also affecting the literary creativity which was being created in the lands of the former Yugoslavia where Albanians lived and worked.

"It has been said and written that Ibrahim Rugova was among the first to oppose this literary direction with his writings published in the press of the time. Indeed, in the writings published in his book, he warned of his orientation aimed at the peaks of world literature, towards the most progressive part of it. He would perfect this orientation after a few months in Paris, France. It can even be freely said that his creativity is related to modernity in Albanian culture, to the modernity of literary and scientific criticism, not only of what was created in the lands of the former Yugoslavia, where Albanians lived, but in all the regions of the world where Albanian language is written. In this way, his works become a beacon that illuminates various aspects of literature, viewed from aspects that until then had not been cultivated in Albanian literature. (Koliqi, 2011, p. 56.)

Therefore, as mentioned above, Ibrahim Rugova's study work begins with "Prekje lirike" (Lyrical Touch), with almost poetic interpretations of literary texts and continues with "Kah teoria" (Towards Theory) which paves the way for Rugova in theoretical-literary research, as the title of the book shows. Specifically, the issue addressed under this title captures theoretical problems of literature, and focuses on the proposal for the artistic text and open art, which means that Rugova never, neither here nor in later works, aims at closing issues. In this sense, his theory goes towards the view of literature as differentia specifica, as a separate artistic production. Apart from the theoretical aspect, Rugova also deconstructs this concept within the Albanian literature, aiming to meet it with the models of world knowledge. The object of such an attempt is to differentiate literature as a separate genre, as an intellectual product, with the aim of searching for the essence of literature. Rugova identifies with the authors he reads and lets them speak, because he will not be an ideologue himself. (Shala, 2011. p. 74.)

Thus, Rugova, as he himself points out, addresses here the problem of methodology. The object addressed is literary criticism which itself has as its object literature.

For Rugova, to criticize means to put in crisis. This includes his opinion that the work is an objective and polysemantic being, and therefore requires open interpretation. Whereas, the interpretation of art, for him, best comes from aesthetic theories and specifically from the aesthetics of ontological objectivism, from where derives the 
aesthetic effect, an effect that comes from the aesthetic object which takes on huge dimensions with a metaphysical function. And, in this case, the work, being understood as meta-physics, lives in cosmic time. Towards theory it is characterized by the concept of literature as differentia specifica, which is illustrated in Albanian literature with the model of world knowledge, as Rugova himself says, to help meet directly with this knowledge.

On the other hand, Rugova's theoretical direction in this work stems from genus proximum, which is explained as the exit of literature from the role of the higher gender, as an introduction to the conception of literature as a separate activity, different from other activities. The direction that starts the journey of addressing literature as such (as special), starting from the literary phenomenon, literature as differentia specifica. (Mehmetaj, 2016, p. 18.) Thus, Rugova theoretically problematizes the differentiation of literature, an issue that requires a look at the state of the superstructure and that emerges conditioned by the movements of the national, social and productive structure, before and now. In this context, he clarifies that the demand on literature for total superstructural heterogeneity should be obliterated, differentiating all the different branches of the exact sciences and the social sciences. Thus, he constantly emphasizes that literature as art can only be demanded to be the art of speech, because only as an artistic product, it will be able to withstand the constant process of differentiation.

\section{The Conception of Rugovian Aesthetic Rejection}

In 1987, Rugova published his latest work, "Aesthetic Rejection”. Rejection here is explained as an opposer to imposition, a path that leads to the building of democracy of life and creative freedom. Recognizing the relationship that literature has with the world, with the man, Rugova sees and analyses rejection in relation to literature and politics. In this context, as its greatest rejection, he considers aesthetic rejection which means rejection with the being and with its character. Thus, aesthetic rejection also affects the cultural historical order. Rugova's ultimate goal is to preserve the basis through aesthetic rejection in order for the literature to remain genuine literature, influencing the power and the society and not vice versa. (Aliu 2006, p. 15.)

Rugova, a literary critic, shines especially when he reads contemporary authors, in the first readings of newly published works. He measures himself with these works, presents and evaluates in the difficult path of the first evaluations which are always the most difficult. The peculiarity of the critic lies in the fact that he appears as a powerful interpreter of literary knowledge and beyond it, as a scholar who seeks deep meanings of literature.

According to literary scholar Sabri Hamiti, the book Aesthetic Rejection, from the form of formal construction seems to be a continuation of the earlier book, Strategy of the Meaning. This is not only because it consists mainly of critical texts related to contemporary authors and current literary works and ideas, but also because its chapters are not named based on the issues examined, but based on the classification of forms of author's criticism. In this view, we have a self-classification of the author's writing. The book Aesthetic Rejection has this structure: I. Essay, II. Criticism, III. Studies, observations, IV. Theory of criticism. Looking at these chapters, which mark the forms of 
criticism, we directly understand the necessary or preferred forms that the critical discourse of this author takes in a permanent dialogue with literary phenomena, with specific works and with Albanian authors. It is natural that the writings related to a specific literary environment and time are connected by a special sensitivity, as well as a host of similar or common formulations and formulas which the author knows and emphasizes in the Preface. He goes one step further there and implicitly seeks critical morality and value to be tested in time. Rugova is already an experienced critic and easily passes his texts in the network of formal and genre classifications. As always, he keeps free the essay form to unfold free ideas, without bothering with their exhaustive argumentation. With this ease of the new idea, he treats the novelist work in the novel, the perception of history in the corpus of novels, the rhetoric of the poetic form, or the interpretive courage to identify a poem, even personal poetics, through a verse. Under the measure of criticism, as a specific interpretation of the specific work and further as a lively dialogue with literary current events, Ibrahim Rugova writes about works in different genres, published during the eighties, by Azem Shkreli, Fahredin Gunga, Musa Ramadani, Teki Dërvishi, Jusuf Buxhovi, Mehmet Kraja, Ibrahim Kadriu, Qerim Arifi, Abdullah Konushevci. All of these writers are of almost the same generation with the critic. He does this as if to prove that the critic of the generation is the best connoisseur of the same literary sensibility which implies a generalization, showing the knowledge of the individual style of the authors which makes them different and special. It is possible that these two elements make Rugova's texts have an almost friendly understanding in the face of a literary discussion.

Rugova defines the concept of aesthetic rejection in principle by analysing both rejection and aesthetics separately. He emphasizes that rejection is non acceptance of what is imposed and that this depends on personal and general attitude. In this logic, rejection is realized in the insoluble aporia of the trichotomous imposition-acceptancerejection relationship. Through rejection, we are freed from pressure or become victims of it. Rugova practically sees two solutions: yes, or no, with different ways of realization. Rejection, here is explained as the antithesis of imposition. (Mehmetaj, 2016, p. 81.)

In his studies, Ibrahim Rugova always leaves the possibility of observing the phenomena from other points of view, even the ones that are different from what he does. This happens because the literary work is observed as a phenomenon that everyone reads and communicates in their own way, depending on the level of theoretical preparation and knowledge of literary practice, receptive aesthetics, but also beyond it. 


\section{References}

1. Albanë Mehmetaj, "Studimet letrare të Ibrahim Rugovës" (Literary Studies of Ibrahim Rugova), Buzuku, Prishtina, 2016.

2. Ali Aliu: Një vështrim mbi perceptimin estetik të veprës së Ibrahim Rugovës (Kumtesë e mbajtur në simpoziumin "Rugova dhe vepra e tij”, me 29 shtator në Tiranë) (A look at the aesthetic perception of the work of Ibrahim Rugova (Paper delivered at the symposium "Rugova and his work", on 29 September in Tirana). Gazeta "55", Tirana, 2006.

3. Engjëll Koliqi, "Dr Ibrahim Rugova - arkitekt i Dardanisë së Re - Republika e Kosovës” (Dr. Ibrahim Rugova - Architect of New Dardania - Republic of Kosovo), RUGOVA ART, Prishtina, 2011.

4. Kujtim M. Shala: Rugova: Qarku i Prishtinës dhe rugovizmi, në librin Prishtina letrare (Acta Albanica: Qarku letrar i Prishtinës) (Rugova: Prishtina Circle and Rugovism, in the book Literary Prishtina (Acta Albanica: Literary Circle of Prishtina), Albas, Tirana, 2011.

5. Kujtim M. Shala: "Rugova meditans”, AIKD, Prishtina, 2008.

6. Sabri Hamiti, "Kritika letrare / Ibrahim Rugova" (Literary Criticism / Ibrahim Rugova), ASHAK, Prishtina, 2007.

7. Ramadan Musliu: "Riaktivizimi i memories letrare (Monografia "Vepra e Bogdanit 1675-1685" e Dr. Ibrahim Rugovës), në librin "Estetikë e dallueshme" (Reactivation of Literary Memory (Monograph “Bogdan's Works 1675-1685” by Dr. Ibrahim Rugova), in the book “Distinctive Aesthetics")), Prishtina, 2003

8. Xhemail Mustafa: Vetëdija mbi tërësinë (Ibrahim Rugova "Kahe dhe premisa të kritikës letrare shqiptare 1504-1983”. Botim i dytë i Euro rilindjes”, Tiranë, 1996) (Awareness on the Whole (Ibrahim Rugova "Directions and Premises of Albanian Literary Criticism 1504-1983". Second edition of Euro renaissance”, Tirana, 1996)). "Bujku”, Prishtina, 13 September 1997, 13, p. 12-18. 